\title{
Biogeomorphologic Approaches to a Study of Hillslope Processes Using Non-Destructive Methods
}

\author{
Pavel Raška \\ Jan Evangelista Purkyně University in Ústí nad Labem, \\ Czech Republic
}

\section{Introduction}

The aim of this chapter is to present new non-destructive methods and techniques used in the biogeomorphologic study of hillslope processes, particularly sheet erosion and shallow landslides. These processes belong to a broad spectre of natural hazards that have significant impacts on landscape and society and their research represents the fundamental issue for applied geomorphology (Panizza, 1996; Alcántara-Ayala, Goudie eds., 2010). Nondestructive methods are not yet well established in biogeomorphologic research despite their relevance in areas protected under conservation law, in fragile habitats and considering their simple field application. To introduce some of these methods in case studies within the context of biogeomorphology, we first give an introduction to the main concepts regarding landform-biota interactions followed by a focus on hillslope processes. In sections 3 and 4 , we present two case studies of the application of non-destructive methods to quantify the bioprotective role of fallen trees (trunk dams, log dams) and to analyse short-term surface stability. In the final section, we suggest possible directions for the future development of non-destructive methods in the biogeomorphology of hillslope processes.

The evolution of Earth's surface in contrast with other planets in the Solar System is characterised by the fundamental role played by organisms, which act directly by creating, modifying and destroying landforms and indirectly by changing other factors that influence surface processes, such as climate and the distribution of energy. Looking at the history of research in this field of expertise, it seems that the significance ascribed to organisms (and particularly to vegetation) within a short history of biogeomorphology grew as rapidly as other fundamental concepts within a hundred year history of geomorphology. Most recently, this trend has led to the assumption that vegetation can indeed be a leading factor in global geomorphic change, and understanding its evolution is crucial to establishing an evolutionary view in geomorphology (Corenblit \& Steiger, 2009). From a case study in eastern Kentucky, for instance, Phillips (2009) concluded that if only $0.1 \%$ of net primary production of biomass is assumed to be geologically active, it still exceeds the energy of uplift and denudation. In spite of these results, one can hardly imagine vegetation being 
responsible for creating the global geomorphic patterns comprising everything from mountain ranges to valleys (cf. Scheidegger, 2007) even though the absence or presence and character of vegetation can modify the rate of landform evolution by protecting the Earth's surface (factor being limited by extent of rhizosphere) or by changes in energy diversification (assuming land cover pattern scale, which is sufficient to influence continental to global climate). Moreover, the role of vegetation in different time horizons (i.e., scale dependency) is unclear. The classic work of Schumm \& Lichty (1965) shows how vegetation changes from a dependent to independent factor through time. More recently, Phillips (1995), at a more local scale, has shown that vegetation may in fact be a dependent variable rather than a controlling factor, which has also been discussed by Raska \& Orsulak (2009).

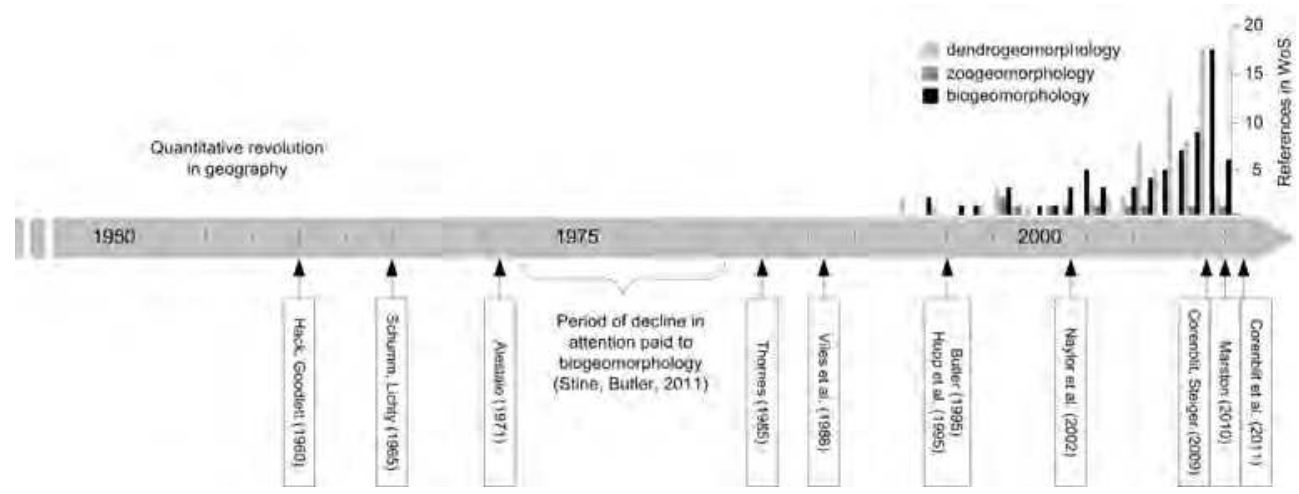

Fig. 1. Major publications devoted to the interaction of organisms and geomorphology shown in historical perspective.

The abovementioned uncertainties in geomorphic significance of organisms are partly caused by the development of the scientific background of biogeomorphology, the conceptualisation of which as a young subdiscipline of geomorphology is still developing. An overview of the main achievements in biogeomorphology as represented by fundamental publications is shown in Figure 1. The first works to discuss the landformorganism relation date back to the 19th century; however, it was not until 1960s that biogeomorphology was established as a research approach by Hack \& Goodlett (1960). The very first attempt to give an overview of the field was in the 1980s, when Viles (in Viles et al. 1988) defined biogeomorphology as a "concept of an approach to geomorphology, which explicitly considers role of organisms". Since then, biogeomorphology has been increasingly pursued in studies across varying environments. According to the Web of Science database (Thomson-Reuters), the annual number of works with biogeomorphology as a focal topic increased from less than five to more than 15 during the last 20 years (Fig. 1). This trend is also apparent in dendrogeomorphologic studies, while the number of zoogeomorphologic papers remains consistently low. This pattern indicates the prevailing appreciation of vegetation, the role of which can be studied at different scales and can be generalised. In contrast to the increasing number of biogeomorphologic papers, it is somewhat surprising that the amount of biogeomorphologic content has decreased in textbooks, being lowest in 1970s (see Stine \& Butler, 2011). 


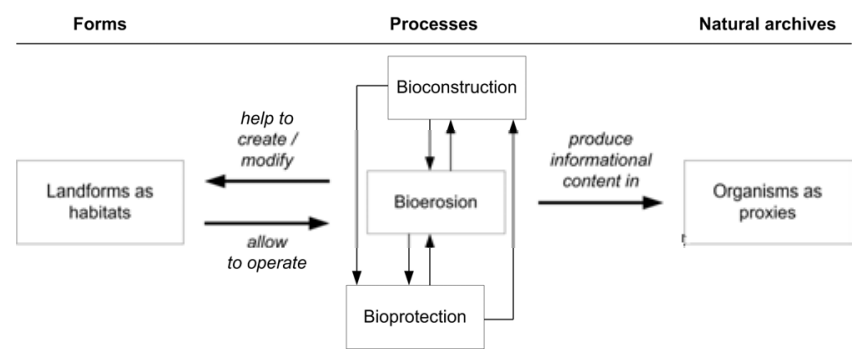

Fig. 2. The thematic framework of biogeomorphology (Naylor et al., 2002; modified by author)

The major aims of biogeomorphology were set by Viles et al. (1988) as (i) the influence of landforms on the distribution of organisms and (ii) the influence of organisms on Earth surface processes, but in fact, the two-way linkages were not fully pursued in the book (cf. Wainwright \& Parsons, 2010). The "revision" of developments in biogeomorphology presented by Naylor et al. (2002) emphasises three main processes interlinking landforms and organisms: (i) bioconstruction, (ii) bioprotection and (iii) bioerosion. The authors call for studies of the complexity of landform-biota interactions. However, organisms were still considered a static factor, and geomorphologists were often unable to avoid the unidirectional appreciation of the landform-organism (vegetation) relation, which has changed only in past few years (e.g., Marston, 2010; Reinhardt et al., 2010; Corenblit et al., 2011).

The problem of a biogeomorphologic focus on two-way linkages is twofold. First, the development of biogeomorphology was accelerated as geomorphology moved from global and regional research scales aiming at historical interpretations of landscape (Church, 2010) to local scales and individual sites as a result of the quantitative revolution and the establishment of the process approach paradigm. The physical background of the process approach emphasised analyses of Earth surface processes and frequently neglected the feedbacks from organisms. Furthermore, a focus on a local scale did not allow the effective modelling of vegetation changes as a response to geomorphic processes because these changes are also influenced by decision-making effects, which are variable and can be better assessed at a regional scale (see Wainwright \& Millington, 2010). One of the possible integrating views to resolve these scale-related problems could be offered by Quaternary landscape ecology, which emphasises evolutionary concepts together with changing patterns of biota and developments in human societies that influence the primary modes of decision making (e.g., Delcourt \& Delcourt, 1988).

The second problem is methodological and emerges from the different backgrounds of the two disciplines integrated within biogeomorphology: geomorphology and ecology. While geomorphologic conclusions are frequently drawn from theoretical considerations combined with detailed field surveys and measurements, ecological conclusions usually result from statistical analyses of extensive datasets (Haussmann, 2011). The prevailing geomorphologic approach, then, only anticipates the real situation, where biota is frequently understood as a static factor or as a source of proxy data for the study of Earth surface processes. Fig. 2 shows the thematic framework of biogeomorphology emerging from 
Naylor et al. (2002) and modified to emphasise the mutual linkages between biota and landforms.

\section{Biogeomorphology of hillslope processes: Main themes and recent advances}

The abovementioned constraints of a study of landform-biota interactions are quite apparent in the research of hillslope processes, as these represent one of the primary focuses of geomorphologists, and the evolution of biogeomorphology was tightly connected with advances in hillslope studies. Hillslopes represent the most common landforms across environments varying from periglacial to tropic regions (e.g., Anderson \& Brooks, 1996 eds.), and they were a key landform in designing fundamental models of landscape evolution, ranging from the classic models of W.M. Davis, W. Penck and L.C. King (for overview see Summerfield, 1991) to modern ones, such as backwearing model by R.V. Ruhe, R.B. Daniels and J.G. Cady, nine-unit model by A.J. Conachre and J.B. Dalrymple, COSLOP by F. Ahnert, and many others. Much of the Earth's surface represented by hillslopes is covered by vegetation, whether a sparse cover of lichens, mosses, grass or less or a more continuous cover of shrubs and trees. Furthermore, the hillslopes are habitats for various animals, some of which prefer gentle slopes covered with a deep soil layer and others that developed a preference for rock-mantled slopes (see Butler, 1995, for overview). At the same time, hillslopes belong among the most dynamic landforms of the Earth's surface, enabling the occurrence and acceleration of different natural hazards, such as sheet and gully erosion, landslides, rockfalls, rock avalanches, debris flows, snow avalanches, and others, which have impacts on the manmade objects and human activities in a landscape (Alcántara-Ayala \& Goudie, 2010 eds.). The enormous share of hillslopes on the Earth's surface together with their dynamics implies the necessity of intense applied research as well as opportunities for the development of new, effective research techniques. Finally, considering the abovementioned distribution of organisms on hillslopes, these techniques frequently draw upon analyses of organisms, whose distribution, activity or physiognomic modifications serve as proxy indicators of hillslope processes, and the primary attention is devoted to vegetation in this respect.

The first work on dendrogeomorphologic responses to geomorphic processes in terms of their chronology was by Alestalo (1971). Since then, many studies have focused mainly on mass movements and erosion. Concerning research on erosion, Thorns (1985) summarised not only the state of the art but also established a framework to understand feedbacks between vegetation and erosion, thus extending the traditional unidirectional approach in biogeomorphology; this was also enabled by his attention to non-linear dynamic systems in biogeomorphology. Most recently, Marston (2010) presents a comprehensive overview of research on hillslope-vegetation linkages, including research history, main functions of vegetation, feedbacks between vegetation and landforms within the disturbance regimes, and suggestions for future research directions.

An overview of the basic approaches and techniques used in the biogeomorphologic study of hillslope processes is presented in Table 1 along with references to some of the major papers published within this scope. Regarding the methods used, these approaches could be divided into three groups. The first one has in common the use of modelling techniques 
based on physical laws, which are quite often calibrated by the results of limited field surveys or laboratory measurements. These approaches are applied mostly in the modelling of changes in vegetation patterns and the related influence on sediment supply, and they often exploit specially developed GIS-based modelling software, such as MIKE 11 or HECRAS, although the incorporation of vegetation parameters into these models is limited.

\begin{tabular}{|c|c|c|}
\hline Aim (process or effect) & $\begin{array}{l}\text { Studied object } \\
\text { (approach) }\end{array}$ & Reference \\
\hline $\begin{array}{l}\text { sheet erosion } \\
\text { - detection, dating }\end{array}$ & $\begin{array}{l}\text { roots (anatomy } \\
\text { analyses) }\end{array}$ & $\begin{array}{l}\text { Gärtner et al. (2001), Bodoque et al. (2005), } \\
\text { Gärtner (2007), Rubiales et al. (2008) }\end{array}$ \\
\hline $\begin{array}{l}\text { sheet erosion } \\
\text { - protective function of } \\
\text { vegetation }\end{array}$ & $\begin{array}{l}\text { vegetation } \\
\text { (modelling) }\end{array}$ & Dorren et al. (2004), Vanacker et al. (2007) \\
\hline $\begin{array}{l}\text { gully erosion } \\
\text { - detection, dating }\end{array}$ & $\begin{array}{l}\text { roots (anatomy } \\
\text { analyses) }\end{array}$ & Vandekerckhove et al. (2001) \\
\hline $\begin{array}{l}\text { shallow landslides } \\
\text { - effect of roots on slope } \\
\text { stability }\end{array}$ & roots (modelling) & $\begin{array}{l}\text { Wu et al. (1979), Abe \& Ziemer (1991), } \\
\text { Preston \& Crozier (1999), Schwarz et al. } \\
\text { (2010) }\end{array}$ \\
\hline $\begin{array}{l}\text { shallow landslides - } \\
\text { protective function of } \\
\text { trees }\end{array}$ & $\begin{array}{l}\text { forest cover } \\
\text { (modelling) }\end{array}$ & Sidle et al. (1985), Bathurst et al. (2010) \\
\hline $\begin{array}{l}\text { landslides } \\
\text { - detection, dating }\end{array}$ & $\begin{array}{l}\text { trunk (tree ring } \\
\text { analyses) }\end{array}$ & Fantucci (1999), Gers et al. (2001) \\
\hline $\begin{array}{l}\text { uprooting } \\
\text { - effect on soils }\end{array}$ & $\begin{array}{l}\text { roots, trunk (field } \\
\text { survey) }\end{array}$ & $\begin{array}{l}\text { Schaetzel et al. (1989), Phillips \& Marion } \\
\text { (2006) }\end{array}$ \\
\hline $\begin{array}{l}\text { rockfall } \\
\text { - detection, dating }\end{array}$ & $\begin{array}{l}\text { trunk (scars, tree } \\
\text { ring analyses) }\end{array}$ & Perret et al. (2006), Stoffel \& Perret (2006) \\
\hline $\begin{array}{l}\text { debris flows } \\
\text { - detection, dating }\end{array}$ & $\begin{array}{l}\text { trunk (scars, tree } \\
\text { ring analyses) }\end{array}$ & $\begin{array}{l}\text { Bollschweiler et al. (2008), Stoffel (2010), } \\
\text { Šilhán \& Pánek (2010) }\end{array}$ \\
\hline $\begin{array}{l}\text { protective effect of fallen } \\
\text { trees } \\
\text { - quantification }\end{array}$ & $\begin{array}{l}\text { trunk (field survey, } \\
\text { modelling) }\end{array}$ & Raska \& Orsulak (2009) \\
\hline $\begin{array}{l}\text { effect of fallen trees } \\
\text { - shaping debris flows }\end{array}$ & trunk (field survey) & Lancaster \& Hayes (2003), Matyja (2007) \\
\hline $\begin{array}{l}\text { soil and regolith } \\
\text { disturbances by animals } \\
\text { - pattern, rate }\end{array}$ & $\begin{array}{l}\text { different species } \\
\text { (field survey and } \\
\text { experiments) }\end{array}$ & $\begin{array}{l}\text { Trimble \& Mendel (1995), Gover \& Poesen } \\
\text { (1998), Hall \& Lamont (2003) }\end{array}$ \\
\hline
\end{tabular}

Table 1. Overview of selected biogeomorphologic approaches to a study of hillslope processes (references are selected to show the different approaches and methodological advances in the field of expertise)

The second group of approaches can be called non-destructive. These approaches focus on measurements and analyses of visible features that represent past or current interactions between vegetation and hillslope processes. To analyse rockfall activity and patterns in protected forests, Stoffel (2005) performed analyses of the distribution and visibility of scars on trees. Attention was also given to log jams shaping debris flows trajectories (Lancaster et 
al., 2003; Matyja, 2007). However, most of these techniques are usually combined with sampling techniques in the field.

The third and most exploited group of approaches, beginning with the classic work of Alestalo (1971), draws upon extensive field research and sampling using different strategies. The samples are usually taken as cores, wedges or cross-sections from stems, stumps and roots (for nomenclature see Gschwantner et al., 2009). Sampling and tree ring analyses are frequently supported by measurements of stem or root deformation, and studies based on this approach have already offered good results regarding the spatiotemporal patterns of rockfall (e.g., Stoffel \& Perret, 2006), debris flow (Bollschweiler et al., 2008) and landslide (e.g., Fantucci, 1999) activity. The application of the approach encounters several problems, however. These problems consist of the number and suitability of tree species for cross dating (Grissino-Mayer, 1993), the availability of reference datasets and other issues (see Stoffel \& Perret, 2006). The number of samples differs according to the extent of the area under research, the time span and type of process being studied (Fig. 3), which result in the varying efficiency of the sampling strategy as expressed by the number of samples per one detected event.

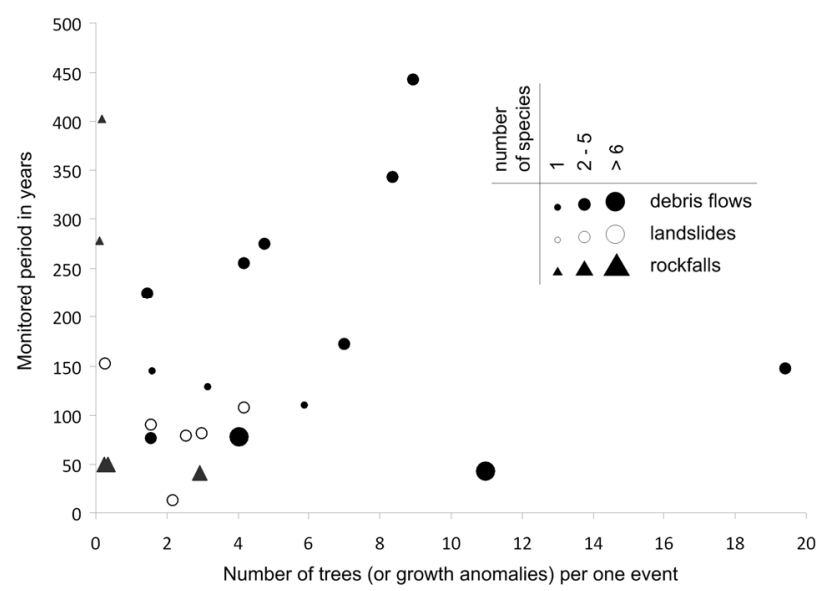

Fig. 3. Number of samples used for the detection and dating of debris flows, landslides and rockfall events in relation to the length of the monitored period in years and to the number of species analysed. Source: based on own review of 25 selected papers published in international journals between 2001 and 2011.

In some areas, however, it is not possible or suitable to take cross-sections and wedges from roots and stems or to measure root geometry deformations after uncovering the soil layer. In these cases, one has to employ non-destructive techniques, which enable the detection of processes and the estimation of their rates from the current positions and visible deformations of vegetation in the field. Moreover, several of the abovementioned destructive approaches focus the enormous potential of information recorded in vegetation species as proxy indicators, which oftentimes leads to maintaining the unidirectional approach to a study of landform-biota relations as discussed in the first section. 


\section{Structure, dynamics and protective effects of trunk dams}

In this section, we will define and characterise trunk dams in terms of their structure, dynamics and protective effects. Then, we will present the recent advances in implementing the results of field research to regional models of the bioprotective effect of trunk dams at a catchment scale using the geographic information systems (GIS). The aim of the developed model is to transfer the local information about the protective effect of individual trunk dams to the regional scale and to estimate the total volume of material retained by fallen trees or trunks.

\subsection{The concept}

The major recent focus of biogeomorphologic (dendrogeomorphologic) studies of hillslope processes is on the protective effects of trees and shrubs. The research is especially carried out in protection forests. The delimitation of protection forests emerges from their general ability to control or modify the natural hazards connected with Earth's surface dynamics (Berger \& Rey, 2004). Different national approaches and nomenclatures have been adopted for the zonation of protection forests and for their management, the difficulty of which emerges from the requirement to maintain both the ecosystem's integrity and the protective function of these forests (Dorren et al., 2004). The protection forests in mountainous areas are predominantly determined for rockfall impact reduction. Most protection forests in highlands and slightly undulating terrains without rock faces have a protective function against soil erosion. In the Czech Republic, where the present study was performed, these forests are called soil-protecting forests (Collective, 2007). In many studies and applied works on protection forests, the focus is on standing trees and shrubs, although Dorren et al. (2007), for instance, also explicitly mention the significance of lying trunks for increasing surface roughness and reducing the velocity of bouncing and rolling clasts of rock. The overall number of biogeomorphologic papers dealing with fallen trees, however, is small, and the issue has been much more in the focus of forest ecologists and biologists.

In forest ecology and management, fallen trees and their large parts are referred to as coarse woody debris (CWD), woody detritus, or downed wood, and a significant ecological role is ascribed to the process of tree death and decomposition (Masser et al., 1984; Harmon et al., 1986; Franklin et al., 1987). Lying trees and their parts increase the habitat diversity in forests, thus increasing biodiversity, as they offer good conditions for the development of mosses, lichens, plants and fungi communities as well as insect (Insecta) and other organisms. Furthermore, the importance of fallen trees lies in their influence on channel diversity in water streams, in the increase of the production function of forests and in the positive influence on the carbon cycle in forests. The ecological significance of fallen trees has led to changes in the traditional forest management approach, the aim of which formerly was the removal of all woody debris (cf. Harmon, 2002).

The trunk dam concept presented here was originally described in Raska \& Orsulak (2009), resulting from the typology of the bioprotective effects of trees at rock-mantled slopes in the Ceske stredohori volcanic mountain range in the NW Czech Republic (Raska, 2007, 2010). In contrast to studies of allochtonous log jams, which often form as a result of mass movements on hillslopes, the present concept emphasises the role of individual trunks (or logs), which, depending on the local surface roughness and density of standing trees, are rather 
autochthonous. The trunk dam forms as the tree or its parts fall and are stabilised by obstacles on the surface. Depending on topography, density, the total length and other characteristics of trunk dams in the area, they can play a significant role in the reduction of the volume of material that is transported downslope. The collective (2007) shows that the amount of dead wood can be higher than $8 \mathrm{~m}^{3}$.ha-1. Vallauri et al. (2003) lists examples from European forests, which show that the volume of dead wood varies from 0.6 to almost $20 \mathrm{~m}^{3}$.ha- ${ }^{-1}$. The total volume of fallen trees depends on the density and diversity of forest cover and on its ecological integrity.
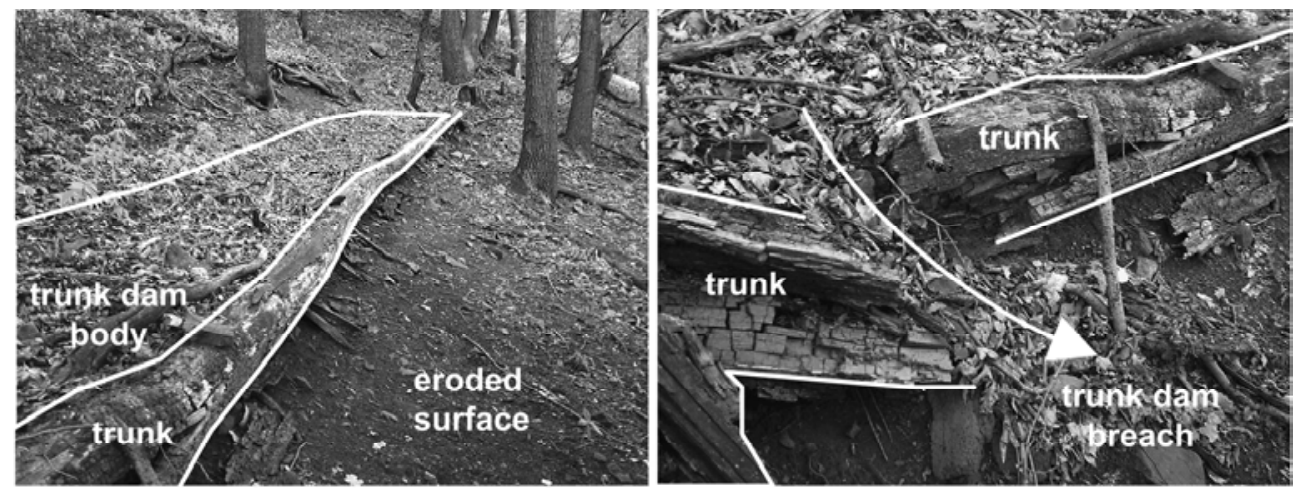

Fig. 4. Trunk dam in advanced stage of plant succession (left), trunk dam breach (right).

\subsection{Structure and dynamics}

A trunk dam is a biogeomorphologic system compound of five components, three of which form the mass of the trunk dam and two of which (base surface, barriers of embedment of a trunk) create its boundaries. The three inherent components are the following (Figs. 4, 5C):

i. Trunk: This component usually appears as a stem with large branches, but sometimes it can also be present in the form of a complete tree or as individual large branches. Depending on surface roughness and trunk geometry, the height of its position above the surface can vary.

ii. Body: The main body of a trunk dam is formed by a mixture of sediments of varying fractions (from clay to angular scree and rounded boulders) and organic components including decomposed parts of plants, litter, etc. Its top can vary from flattened (cf. Matyja, 2007) to rough and inclined at locations, where the base surface has a higher inclination and where the trunk dam is subject to further impacts of rolling and bouncing clasts. The internal structure of the body depends on the evolutionary history of each trunk dam and the type of material, which is delivered from the upper parts of the hillslope. The bodies of the newly formed trunk dams include an unsorted mixture of material, but when the trunk dam is stabilised for longer time, the body can display stratification as a result of the sequence of events that delivered the material to the trunk dam and/or as a result of a sieve effect and sorting within the trunk dam body. An example of a trunk dam with such a partly stratified body as detected during the field survey (Raska \& Orsulak, 2009) is shown in Fig. 5C. 

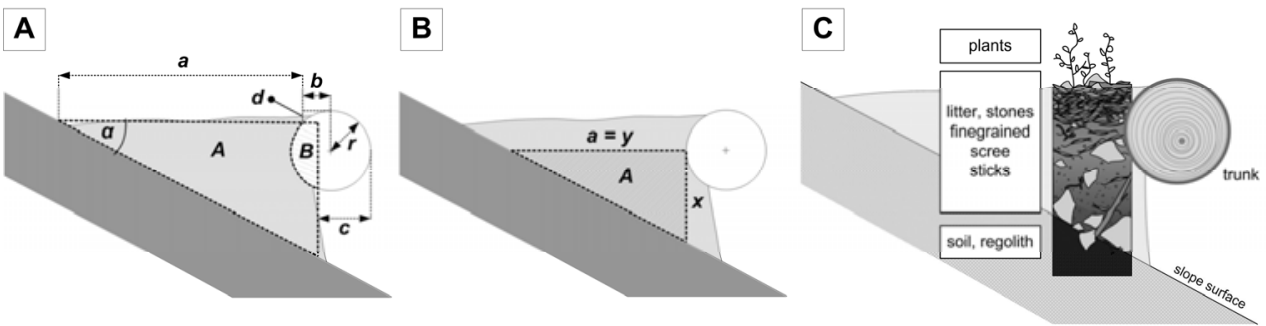

Fig. 5. Cross-section through the trunk dam. A - real (grey) and theoretical (black dashed) geometry of trunk dam with parameters measured in the field (lower case) and computed values (upper case); B - simplified trunk dam geometry used for spatial modelling (see section 3.3); C - structure of a trunk dam body.

iii. Cover: Trunk dams that have been stabilised long enough are covered by plants. The dynamic habitat of trunk dams is suitable for pioneer species. The results of a field survey in the study area show that the plants inhabiting trunk dams often belong to invasive species (e.g., Impatiens glandulifera). The speed of colonisation and the relative importance of species depend on the type of environment in which the trunk dam is located (McCullough, 1948). The fast colonisation of a trunk dam surface accelerates the stabilisation of its body through plant roots. While the body of a trunk dam is colonised mostly by herbs, the trunk itself in different stages of decay represents a habitat for mosses and especially fungi (e.g., Bader et al., 1995).

One of the aims of our previous research was to design a simple non-destructive method for estimating the volume of material accumulated by trunk dams. After initial attempts, an MS Excel Spreadsheet was designed. The EVAM (Estimation of Volume of Accumulated Material v1.0, available at <http://lsru.geography.ujep.cz $>$ ) approximates the cross-section of a trunk dam to a simple triangle-like shape (Fig. 5A), and it enables an accurate estimation of the volume of accumulated material (VAM).

The first results, which compared the accumulation and denudation rates in two sampling sites (Raska \& Orsulak, 2009) showed that in terms of the current dynamics of a hillslope surface, the accumulation rate may be as important as the denudation rate. The overall results for 26 trunk dams analysed at three sites within the studied catchment revealed certain relations between the individual geometric parameters of a trunk dam (Fig. 6A). The highest correlation is between accumulation width "a" and VAM, but it will be shown later that there are certain difficulties in the generalisation of this relation. By contrast, a weak correlation was revealed between trunk radius " $\mathrm{r}$ " and VAM. However, the trunk radius and geometry of a trunk may partly influence other values, such as "a" and the height of a trunk above the surface.

The height of a trunk above the surface represents one of the most important factors influencing VAM values, as will be shown in relations between the width of accumulation, the slope inclination and VAM (Figs. 6B and 6C). Fig. 6B shows how VAM grows with increasing slope inclination. The model assumes that the height of a trunk above the surface is a dependent variable calculated from other input parameters. By contrast, the model in Fig. 6C assumes the trunk dam is in contact with the surface and, thus, is an independent variable. In this case, the higher is the slope inclination, the lower is the VAM. 

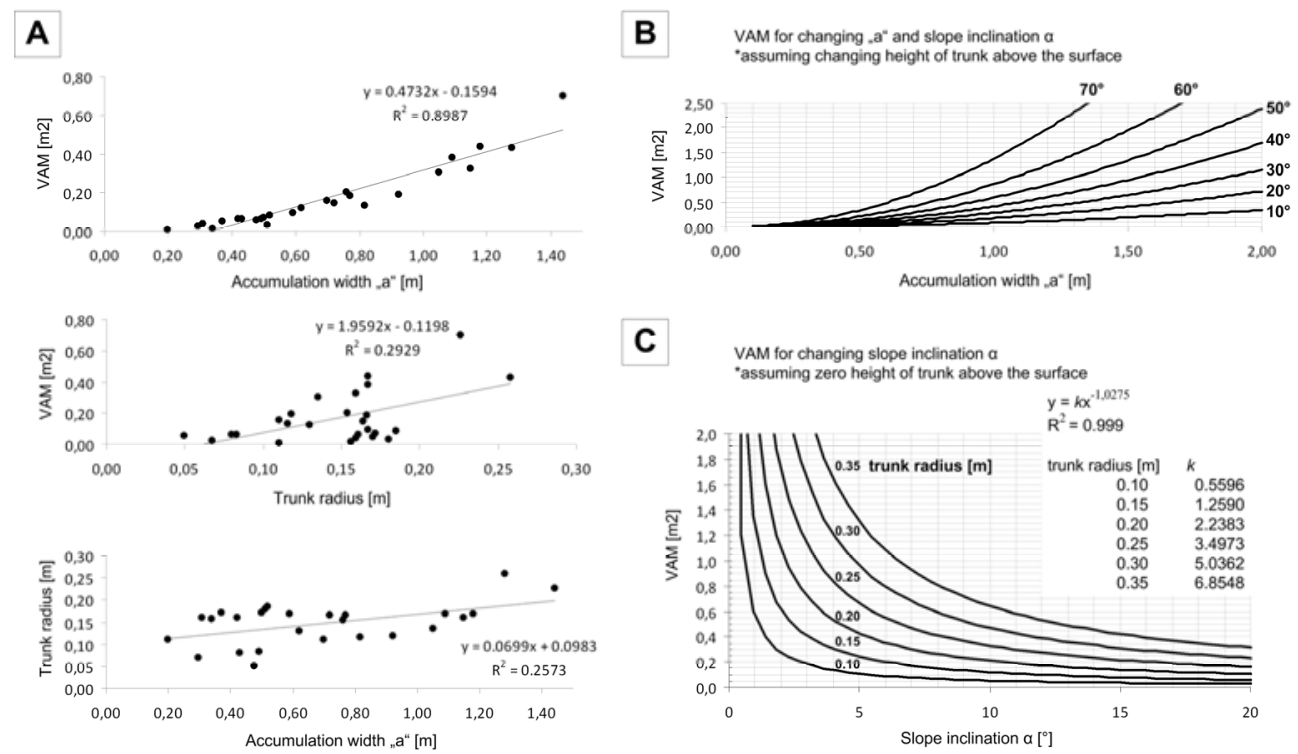

Fig. 6. A - relationship between measured parameters and the volume of accumulated material (VAM) in the dataset from a field survey; B, C - theoretical values of VAM and "a" for varying and for stable (zero) height of trunk above the surface (see text for further explanation).

As we discussed in section 3.1, the reason for the biogeomorphologic study of trunk dams is their ability to decelerate the velocity of rolling and bouncing clasts and their protective role against sheet erosion. The protective function against clasts, which move downslope as a result of rockfall events, is enabled by the trunk acting as a barrier and by the deceleration of clasts at the flattened top of a trunk dam (Raska, 2007). The bioprotective effect against sheet erosion is more complex, and its significance varies in the different parts of a trunk dam. In general, the bioprotective effects against sheet erosion could be direct and indirect. The direct effects consist of the accumulation of allochthonous material in the body of a trunk dam for a certain time. The indirect effects emerge from local feedbacks between trunk dam ecology and surface dynamics. As trunk dams are colonised by plants, they reduce soil erosion by the following:

- interception and deceleration of the velocity of raindrops falling on the ground;

- enhancing infiltration through root systems and increasing soil aggregate stability;

- transpiration of soil water, thus decreasing water content in soil;

- $\quad$ increasing surface roughness by roots, fallen leaves, etc.;

- increasing the volume of organic substances in the soil (Trimble, 1988; Gyssels et al., 2005).

However, the surface below the trunk dam often displays higher rates of denudation, as the trunk dam body retains all the sedimentary material. Also, the overland flow, which continues downslope, has higher erosive energy (see Fig. 4). 
The fundamental point in the evaluation of the protective effect of trunk dams is the time scale in which they can effectively protect the surface against erosion. The stability of a trunk dam depends on several factors and can be expressed by the following equation:

$$
S=f .\left(E_{s, e, d, p}, I_{p, w, m}\right)
$$

where:

- E ... external factors (s - slope inclination, e - embedment, d - disturbations, p stabilisation by plants), and

- I ... internal factors ( $\mathrm{p}$ - position of a trunk dam, w - wood characteristics, including strength, geometry and stage of decomposition, $\mathrm{m}$ - structure of material within the trunk dam body).

The role of these factors is summarised in Table 2. The persistence of a trunk dam is limited by the total decomposition of the trunk and emptying of the accumulated material or by the breach of a trunk dam. Nevertheless, in some cases, the body of a trunk dam can be stabilised by plants to such an extent that even the total decomposition of a trunk will not result in the destruction of a trunk dam (see the three-way development model in further text).

\begin{tabular}{|l|l|l|}
\hline Factor & Stability & Instability \\
\hline slope inclination & lower slope inclination & higher slope inclination \\
\hline embedment & $\begin{array}{l}\text { embedded by standing } \\
\text { trees }\end{array}$ & $\begin{array}{l}\text { embedded by surface } \\
\text { roughness }\end{array}$ \\
\hline disturbances & no impacts & rockfall, zooturbation \\
\hline stabilisation by plants & with plant cover & without plant cover \\
\hline position of a trunk dam & transverse & downslope \\
\hline $\begin{array}{l}\text { wood characteristics (strength, } \\
\text { geometry and stage of decomposition) }\end{array}$ & $\begin{array}{l}\text { large trunk radius, } \\
\text { straight trunk, early } \\
\text { stage of decomposition }\end{array}$ & $\begin{array}{l}\text { small trunk radius, } \\
\text { curved trunk, late stage } \\
\text { of decomposition }\end{array}$ \\
\hline $\begin{array}{l}\text { structure of material within the trunk } \\
\text { dam body }\end{array}$ & $\begin{array}{l}\text { stratified, } \\
\text { interconnected with } \\
\text { base surface }\end{array}$ & $\begin{array}{l}\text { not stratified, } \\
\text { discontinuity between } \\
\text { trunk dam body and base } \\
\text { surface }\end{array}$ \\
\hline
\end{tabular}

Table 2. Factors influencing the stability of a trunk dam.

Related to the stability issues is the necessity to evaluate the persistence of the protective effect of trunk dams over time. It emerges from the very nature of the problem that the protection given by fallen trees, which are subject to gradual decomposition, will be effective only at small time scales, i.e., from the fall of the tree to its total decomposition or breach (Fig. 4). According to the results of the field survey, the age of individual trunk dams varied from a few days (newly fallen trees) to more than a year. The dating of a trunk dam can be performed by analysing the following indicators:

- the stage of trunk decomposition - large pieces of wood decay relatively slowly. Harmon et al. (1986) has shown that in temperate regions, half-time decay can vary from $25 \mathrm{yr}$ (Quercus) to $150 \mathrm{yr}$ (Pseudotsuga). Schowalter et al. (1992) conducted an 
experiment to assess the decomposition process of four species (Pseudotsuga, Tsuga, Abies and Thuja) and concluded that the decomposition is significantly influenced by the initial wood chemistry and by the colonisation pattern, especially the penetration of the bark barrier and colonisation by wood fungi. Harmon et al. (2000) have presented a new method for estimating biomass loss by wood decay. Their results have shown that in most cases, the biomass loss has negative exponential progress, while in one case (Pinus sylvestris), the regression trend was polynomial, displaying different phases of decomposition. The relative dating of trunk decomposition is usually made by distinguishing categories of (i) hard timber, (ii) edge soft - centre hard, (iii) edge hard centre soft and (iv) totally rotten (e.g., Collective, 2007);

- the internal structure, stratification and compaction of the accumulated material (although this can also reflect initial processes that are responsible for the accumulation of material);

- the stage of plant succession on the top of the trunk dam body;

- the age, distribution and position of the wood fungi, which is to be discussed in section 4.

Based on the field survey, Raska \& Orsulak (2009) proposed a hypothetical model of the three-way development of a trunk dam in the mid-segment of the hillslope. The three ways are the following: (i) stabilisation of the trunk dam by vegetation cover, (ii) dam breach and formation of a new trunk dam and (iii) denudation after the dam breach without the formation of a new trunk dam.

\subsection{Modelling the protective effect at a catchment scale - A first glimpse}

In the next step, after the field research and after designing the method for estimating the volume of accumulated material, our aim was to exploit the results in the regional model at a catchment scale, as simple regional modelling is the very effective way to implement the results into the decision making process. Until now, there have been several models developed for the quantification of erosional rates within small catchments, some of them mentioned earlier in the text. A comprehensive summary of these models is presented by Gyssels et al. (2005), with special attention paid to the role of vegetation in these models. All of these models confirm the increase of soil erosion with the decreasing percentage of vegetation cover.

Gyssels et al. (2005) also show that these models ascribe a protective role to biomass above the surface, but give little attention to the roots. Moreover, many of these models are designed for grasslands and agricultural plants, but the protective role of forests against soil erosion is much higher (Kirkby, 1980). As the monitoring and quantification of fallen trees in forest ecosystems is difficult, the traditional models incorporate variables related to living (standing) trees, i.e., to forest canopy structure. Therefore, we had to establish a new model to simulate the regional protective effects of trunk dams.

We used the GIS-based distributed (GRID-based) model that was applied to the experimental catchment, and the input values were set according to the results of the field survey. The first results of modelling were based on a simplified VAM equation implemented in the GIS environment (ESRI ArcView 3.2, ArcGIS 9.2). 


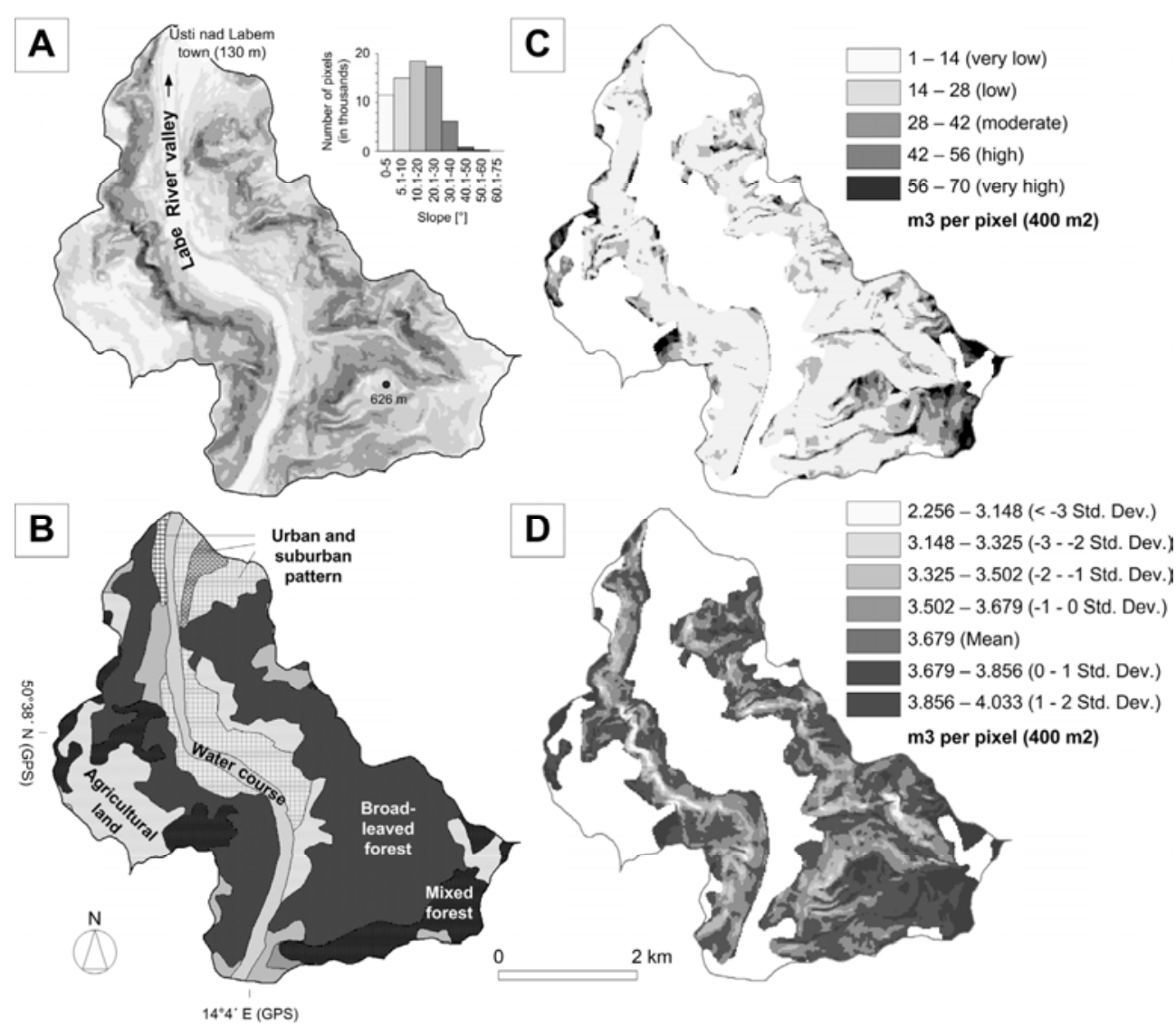

Fig. 7. Model of the protective effect of trunk dams within the experimental catchment. A slope inclination derived from DEM (1:10000); B - land cover classes CORINE 2006; C hypothetic calculated volume of accumulated material; D - calculated volume of accumulated material weighted by slope inclination (pixel size 20x20 m). Data sources: CORINE 2006 (European Environmental Agency), digital elevation data (CUZK).

The cross-section of a body of a trunk dam was assumed to be in contact with a trunk and having the shape of a rectangular triangle (Fig. 5B). Thus, the only necessary values for the calculation of VAM were the accumulation width " $a$ ", the length of trunk " $\mathrm{L}$ " and the slope inclination " $a$ ". Instead of trunk radius " $r$ ", we set the average " $x$ " value (Fig. 5B) calculated from the field survey results. The variability of this value depends on the forest structure and age within the modelled catchment and on the surface roughness influencing height of a trunk above the surface. In the present study, the structure and age of forests is relatively uniform (Fig. 7B). There are no significant differences in trunk radius variations among the studied sites, and therefore, we set the uniform " $x$ " value $(0.35 \mathrm{~m})$. Similarly, the length of trunks was set as an average from the field survey, which was 2500 m.ha-1. Thus, the results of the simplified VAM model will correspond only to the expression of slope inclination. The slope inclination was derived from a digital elevation model (DEM; Fig. 7A). The pixel 
size of distributed model was set to $400 \mathrm{~m}^{2}$, which reflects the precision of the input digital data (cf. Hengl, 2006). As the accumulation width is calculated from slope inclination and the " $x$ " value, it can reach high values in locations with flat terrain; but, in fact, the accumulation width is always limited by the neighbouring trunk dams. The maximum accumulation width can be derived from a simple equation assuming the regular distribution of trunk dams:

$$
\max \mathrm{a}=\mathrm{PS}^{2} / \mathrm{tL}
$$

where PS is pixel size (i.e., $20 \mathrm{~m}$ for a pixel area of $400 \mathrm{~m}^{2}$ ), and $\mathrm{tL}$ is the total length of trunks per pixel (i.e., $100 \mathrm{~m}$ ). The result is a maximum accumulation width of $4 \mathrm{~m}$, which was the value put as an upper limit into the model before acquiring the results of VAM.

The results of the modelling are shown in Fig. 7C, indicating that VAM varies between 1 - 70 $\mathrm{m}^{3}$ per $400 \mathrm{~m}^{2}$, i.e., $25-1750 \mathrm{~m}^{3}$.ha-1, but these values seem to be far from the real situation. The reason is that the " $x$ " value was set constant, and therefore, the model assumes that the lower the slope inclination, the higher the accumulation width (see above) and VAM (see also Fig. 6C). In fact, the real processes operating on low gradient slopes will hardly enable accumulation of the material in the trunk dam with a similar efficiency as on highly inclined slopes. Evidently, there are other factors that influence the potential of trunk dams to be filled with accumulated material, such as the length of slope above the trunk dam, the surface material on the slope, and the disturbance regimes affecting the movement of material (e.g., overland flow, zoodisturbances, forest management measures). However, the slope inclination tends to be the most important of these factors according to our observations. The model (Fig. 7C) was therefore weighted again by the slope inclination to give higher importance to slopes with a high gradient and vice versa. The results of VAM in Fig. 7D vary between $2.2-4.0 \mathrm{~m}^{3}$ per $400 \mathrm{~m}^{2}$, which corresponds quite well to the empirical values gained during the field survey. Nevertheless, the development of the model is still in progress, and the results may differ when computed for more variable input values.

\section{Interpreting active hillslope processes using polypore species}

The indication and dating of hillslope processes connected with biotic communities is limited by the suitability of species (see in the previous sections) and by the time scale pursued by the research. Whereas the former applications of dendrochronologic dating focused on the identification of processes that occurred on a scale of years to hundreds of years (Stoffel et al., 2005; for overview see Fig. 3), and effort has been made to extend the time-span of reference datasets, the dating of current dynamics encounters several problems. Aside from minimal time, which is necessary for tree-ring growth, there are further constraints regarding the differences in the wood anatomy of different species and the limits of dating decomposed trunks. Dating at a time scale of months to a few years, therefore, calls for other proxy data.

An opportunity is given by a study of the succession of organisms at newly established habitats that have been formed as a result of Earth surface dynamics (e.g., Beschel, 1961; Pérez, 2010). Considering hillslope processes, these habitats may include log jams and trunk dams, which are colonised by various species (Masser et al., 1984). In this section, we focus on polypores (Polyporales). 
Polyporous fungi belong to dead-wood-dependent organisms, and they contribute to the continuity of forest renewal by accelerating wood decay processes. The fungi-accelerated wood decay, in turn, improves the integrity of forest ecology and, therefore, the ecology of polypores must be reflected in forest management approaches (Lindblad, 1998). The diversity and abundance of polyporous fungi depends on the species diversity of trees, forest connectivity and the number of downed logs (Edman \& Jonsson, 2001; Hottola, et al. 2009). Species richness also plays a role in the decay stage of wood and tree diameter, although the latter relation is a current topic of discussion (Junninen \& Komonen, 2011). Although some polypores are able to establish ectomycorrhizal relationships, most polypore species are wood-dependent parasites, saprotrophs and necrotrophs. The reproduction principles and their relation to life histories and the diversity of polypore species are well discussed by Kauserud et al. (2008).

\begin{tabular}{|l|l|}
\hline Specie & Habitat \\
\hline Climacocystis borealis (Fr.) Kotl. \& Pouzar & conifers \\
\hline Trichaptum abietinum (Dicks.) Ryvarden & conifers \\
\hline Fomitopsis pinicola (Sw.) P. Karst. & both conifers and broad-leaved trees \\
\hline Chondrostereum purpureum (Pers.) Pouzar & both conifers and broad-leaved trees \\
\hline Ganoderma applanatum (Pers.) Pat. & mostly broad-leaved trees \\
\hline Daedalea quercina (L.) Pers. & broad-leaved trees (especially Quercus) \\
\hline Daedaleopsis confragosa (Bolton) J. Schröt. & broad-leaved trees \\
\hline Fomes fomentarius (L.) J. Kickx f. & broad-leaved trees \\
\hline Phellinus igniarius (L.) Quél. & broad-leaved trees \\
\hline Plicaturopsis crispa (Pers.) D. A. Reid & broad-leaved trees \\
\hline Trametes hirsuta (Wulfen) Pilát & broad-leaved trees \\
\hline
\end{tabular}

Table 3. Selected Central European polypore species suitable for the indication of log jam dynamics and their usual habitats.

The fundamental importance for biogeomorphologic studies is represented by the basic ecological and morphological characteristics of polypores, especially the following:

- $\quad$ relation of polypores to concrete tree species (relation to conifers or broad-leaved trees see Table 3 for overview of selected polypore species);

- colonisation rates on downed wood;

- maximal density of individuals;

- $\quad$ their position on downed wood (horizontal growth of individuals, groups);

- age of individuals - the age of a log jam may be deduced from the largest individual similar to the techniques used in the lichenometric dating of rock surfaces (Beschel, 1961), but at smaller time scales;

- $\quad$ growth rates (annual and perennial, visibility of increments);

- morpholgy of individuals and their deformations (tilting, rotation). 


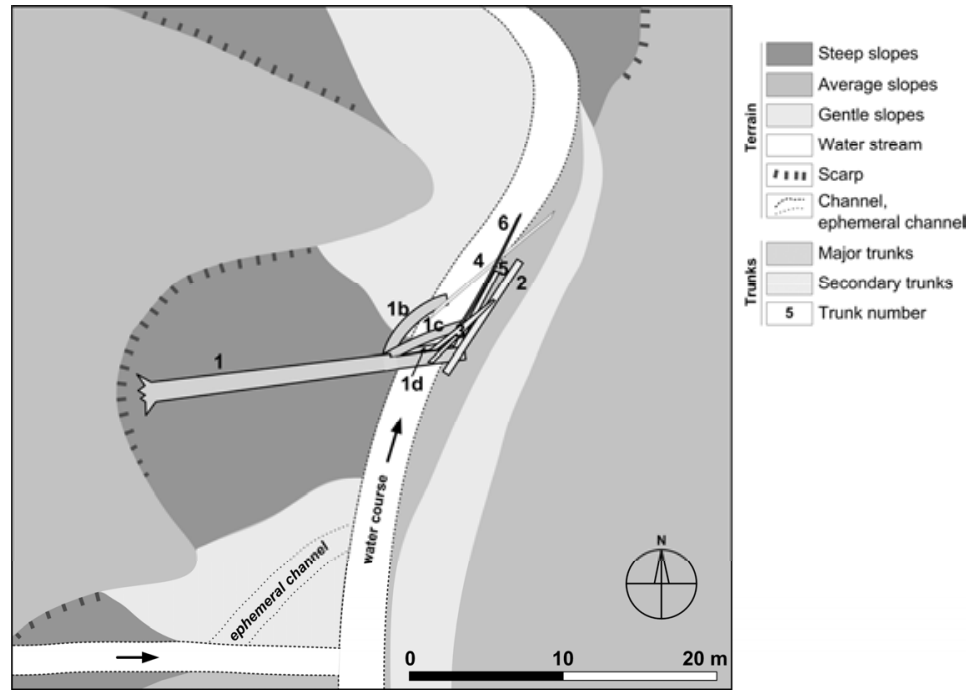

Fig. 8. Geomorphologic sketch of the study site showing the positions of trunks in the channel of a small water stream.

Polypores, which are suitable for the interpretation of the evolutionary history of log jams and fallen trees, predominantly grow horizontally with detectable increment rates. The indication of hillslope processes (erosion, shallow landslides) that affected the log jams and fallen trees is then allowed by the identification of the deformations of individuals. The most common deformations are tilting from the horizontal position and abnormal increments caused by the rotation of the host wood.
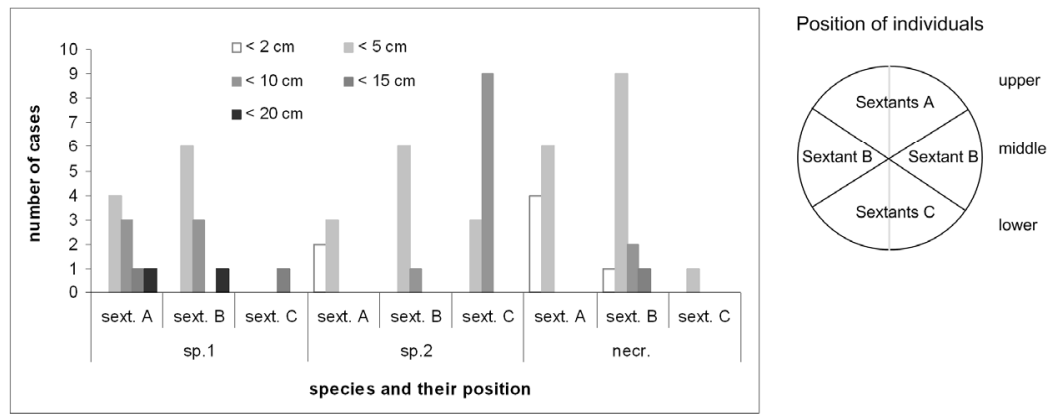

Fig. 9. Position of polypores on trunk number 1 and 1c (Fig. 8). Sp. 1 - Fomitopsis sp., sp. 2 Daedalea sp., necr. - decomposed individuals.

We have carried out a detailed case study of the dynamics of a log jam in a small water stream and compared it with other examples from Central European forests. Fig. 8 presents a geomorphologic sketch of the study site with a log jam in the channel. The log jam was formed as a result of tree downing induced by lateral erosion in a deeply incised channel. After the major trunk was embedded in the channel, it stopped other allochthonous coarse 
woody debris. To understand the evolutionary history of the log jam, we analysed the distribution of polypore individuals on the major trunks located in the channel. The results indicate that different polypore species are located in variable positions within the trunk both in terms of the cross-section position through the trunk (Fig. 9) and of the position along the trunk. The typical morphology of the present species is depicted in Fig. 10. The deformations of individuals and the relation of different types of species and of living and decomposed polypores to positions within the trunk allowed us to specify the major events in the dynamics of the log jam.

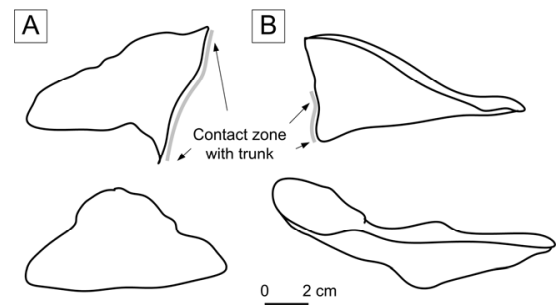

Fig. 10. Front and side views of the polypores on trunk number 1 and 1c. A - Fomitopsis sp., B - Daedalea sp.
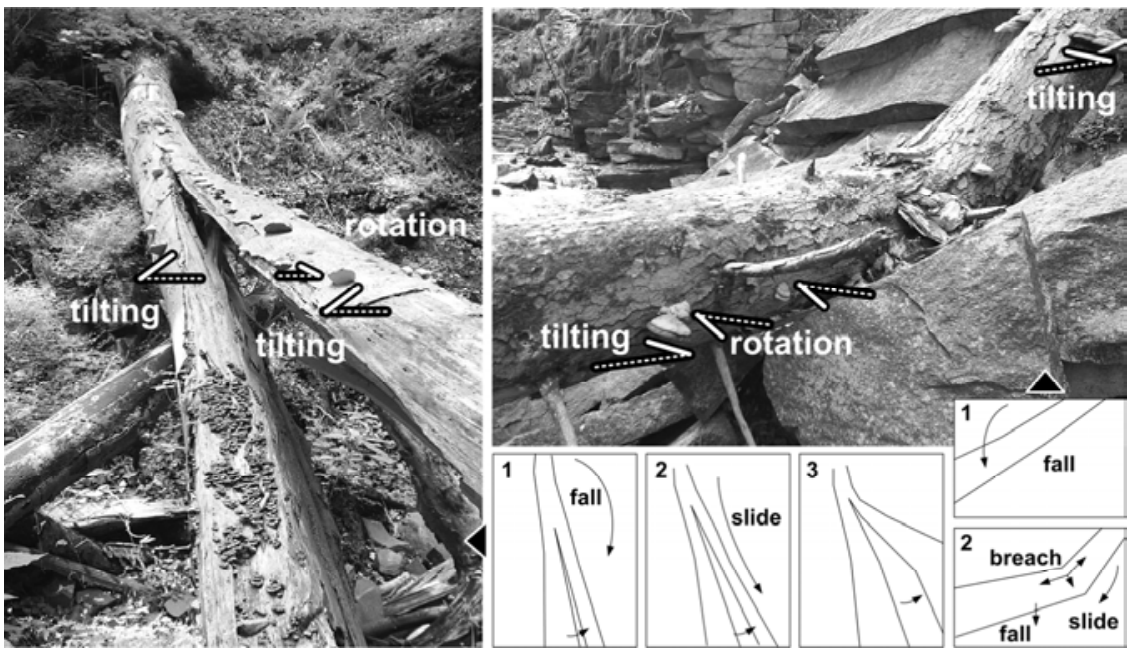

Fig. 11. Interpretation of the evolutionary history of two log jams based on polypore anatomy. The actual position after disturbance is shown by the white line and the hypothetic horizontal position by white dashed line. The black and white schemes in the right bottom depict evolutionary histories of the two log jams.

While the minimal height of living individuals above the water surface was approximately $0.5 \mathrm{~m}$, the dead individuals were frequently located in the contact zone with the water surface. The presence of old decomposed polypores in an unsuitable position in contact with the water surface indicates the occurrence of an event that moved the trunk downward. The tilting and rotation of individuals caused by the movement of the host trunk is shown in Fig. 
11, which depicts sample trunk number 1 (Fig. 11 left; see position in Fig. 8) and a comparative case of log jam from Western Carpathians (Fig. 11 right). The reconstruction of evolutionary history based on the identification of tilting and rotation determined the main processes that play a role in consecutive stages of log jam evolution and the interrelation with the surface morphology and dynamics of the locality. These processes include the initial fall of the tree, sliding, rotation and trunk breach.

\section{Future directions of non-destructive biogeomorphology at hillslopes}

Biogeomorphology is presently one of the most progressive branches of geomorphology, and thanks to its interdisciplinarity, it easily finds several issues in common with ecology, geobiology, and forest management, thus contributing significantly to the complex appreciation of Earth surface systems. The traditional unidirectional approach to a study of landform-biota interaction has gradually extended to cover the two-way linkages and feedbacks between Earth surface processes and landforms on the one hand and organisms on the other. Along with theoretical considerations, many studies show the feedback at concrete localities by employing different techniques. The biogeomorphologic research of hillslope processes is, however, traditionally engaged with destructive methods, such as dendrogeomorphologic sampling and exposure. These methods have been widely exploited in spatiotemporal analyses of mass transport in both high-altitude (e.g. rockfall, debris flows, etc.) and mid-altitude (e.g. landslides and sheet erosion) environments. The studies were carried out in order to understand regional geomorphologic effects of global environmental change (e.g. Evans, Clague, 1994) as well as to provide a scientific background for applied management measures (Panizza, 1996). On the other hand, the nondestructive techniques have been rather overlooked in this respect.

Non-destructive methods offer at least three important advantages, however. First, they can be applied in areas where destructive techniques cannot be performed. Second, they enable the performance of relatively fast and extensive field research in contrast to destructive sampling strategies, even though their results may not be as comprehensive, and there are still problems, which can be studied only by means of destructive sampling strategies (e.g., dendrochronology). Finally, these methods enable the study of some of those landformbiota interactions, which have been neglected. In some cases, these methods may also represent the only effective technique to study these interactions (e.g., short-term surface dynamics). In this respect, we see opportunities that should be more deeply explored by geomorphologists and which, in turn, certify the need for a bidirectional framework of biogeomorphology by employing ecological, ethological and biological knowledge. To name just one of the topics in which biogeomorphologists may more intensively draw upon nondestructive techniques, we would like to mention zoodisturbances at hillslopes.

As was mentioned in the first section, zoogeomorphology remains a "little sister" of dendrogeomorphology. Butler (1995) has shown the influences of the wide spectre of animals on Earth surface processes and landforms; however, only a few of these influences are studied systematically. The main focus has been burrowing animals (Hole, 1981; Volsamber \& Veen, 1985) and animal trampling at rock-mantled slopes and in grasslands. The studies performed usually engaged experiments with manipulated animal density (e.g., Govers \& Poesen, 1998) or detailed field mapping and soil sampling to reveal the physical and chemical properties of 
grazed land (Cluzeau et al., 1992; Trimble \& Mendel, 1995). Despite producing important information about the rates of animal induced surface dynamics, these studies are scale dependent because their methodical background is time-exhaustive (detailed mapping and experiments). The opportunity to generalise the results of these studies lies in drawing from ethological information about the ecological behaviour of the studied species.

The example for consideration will be given from the study area, which was presented in the case studies in this chapter. The forest ecosystems of the studied catchment are diversified by patches of rock-mantled slopes and talus scree deposits, which have formed by the disintegration of rock-cliffs built by basaltic rocks since the Late Glacial Period. There are more than 100 such talus slope deposits exceeding an individual area of $400 \mathrm{~m}^{2}$. During the study of these deposits, we focused on different types of processes, among which zoodisturbances tend to play an important role. Nevertheless, the monitoring of animal trampling on talus slope deposits exceeded the possibility of the research, so the other approach had to be adopted. The major trampling specie in the area is mouflon (Ovis musimon), which is an introduced specie in the Czech Republic (Heroldova \& Homolka, 2001). As shown by Cransac \& Hewison (1997), the seasonal activity and selection of habitats of mouflon hordes in their original environment is dependent on several variables, such as feeding activity and climate. During the year, the hordes are partly bound to rocky habitats. In our study area, it was confirmed by observation that talus slope deposits indeed represent an alternative habitat for mouflon hordes. The information about mouflon ethology together with the observation at talus slope deposits, where the presence of mouflon hordes was confirmed, enabled the specification of results from the field mapping of microtopographic features (especially clast flows) present on talus slope deposits (Raska, 2010). A similar approach could be applied to reveal the spatial behaviour and specific effects of other trampling species or burrowing animals.

To summarise, we are aware that there are many biogeomorphologic studies that are relatively close to non-destructive approaches, but were not mentioned in this chapter due to its limited extent. We refer readers to more complete reviews of biogeomorphology, dendrogeomorphology, and zoogeomorphology as well as the problem of soil erosion, which is too broad to be discussed in detail herein. The main aim of the chapter was to emphasise the importance of non-destructive biogeomorphologic approaches for a better understanding of the interwoven relationships between the Earth surface and organisms and to document this with two methods, which are currently being developed and applied at the catchment scale within the presented case studies.

\section{Acknowledgements}

Certain parts of the research were performed thanks to financial support from the research project IGA UJEP Disturbance regimes in the Quaternary morphogenesis of the Elbe river valley in the central part of the Ceske stredohori Mts. The author would like to thank Language Editing Services for the English style revision.

\section{References}

Abe, K. \& Ziemer, R.R. (1991). Effect of Tree Roots on Shallow-Seated Landslides. USDA Forest Service Gen. Technical Report PSW-GTR, Vol.130, pp. 11-20 
Alcántara-Ayala, I. \& Goudie, G. eds. (2010). Geomorphological hazards and disaster prevention. Cambridge University Press, Cambridge

Alestalo, J. (1971). Dendrochronological interpretation of geomorphic processes. Vol.105. Soc. Geographica Fennia, Helsinki

Anderson, M.G.; Brooks, S.M. eds. (1996). Advances in hillslope processes, 1, 2. John Wiley \& Sons., Inc., New York

Bader, P.; Jansson, S. \& Jonsson, B.G. (1995). Wood-inhabiting fungi and substratum decline in selectively logged boreal spruce forest. Biological Conservation, Vol.72, pp. 355-362

Bathurst, J.C.; Bovoloa, C.I. \& Cisneros, F. (2010). Modelling the effect of forest cover on shallow landslides at the river basin scale. Ecological Engineering, Vol.36, pp. 317327

Berger, F. \& Rey, F. (2004). Mountain protection forests against natural hazards and risks: new French developments by integrating forests in risk zoning. Natural Hazards, Vol.33, pp. 395-404

Beschel, R.E. (1961). Dating rock surfaces by lichen growth and its application to glaciology and physiography. In: Geology of the Arctic, 2, G.O. Raash, (Ed.), 1044-1062, University of Toronto Press, Toronto

Bodoque, J.M.; D’1ez-Herrero, A.; Martín-Duque, J.F., Rubiales, J.M.; Godfrey, A.; Pedraza, J.; Carrasco, R.M. \& Sanz, M. A. (2005). Sheet erosion rates determined by using dendrogeomorphological analysis of exposed tree roots: two examples from Central Spain. Catena, Vol.64, pp. 81-102

Bollschweiler, M.; Stoffel, M. \& Schneuwly, D.M. (2008). Dynamics in debris-flow activity on a forested cone - A case study using different dendroecological approaches. Catena, Vol.72, pp. 67-78

Brang, P.; Schönenberger, W.; Ott, E. \& Gardner, B. (2001). Forests as protection from natural hazards, In: The forest handbook, J. Evans, (Ed.), 53-81, Wiley \& Sons, Inc., New York

Butler, D.R. (1995). Zoogeomorphology: animals as geomorphic agents. Cambridge University Press, New York

Church, M. (2010). The trajectory of geomorphology. Progress in Physical Geography, Vol.34, pp. 265-286

Cluzeau, D.; Binet, F.; Vertes, F.; Simon, J.C.; Riviere, J.M. \& Trehen, P. (1992). Effects of intensive cattle trampling on soilplant-earthworms system in two grassland types. Soil Biology and Biochemistry, Vol.24, pp. 1661-1665.

Collective (2007). National forest inventory in the Czech republic 2001-2004: Introduction, Methods, Results. UHUL, Brandýs nad Labem (Czech Republic)

Corenblit, D. \& Steiger, J. (2009). Vegetation as a major conductor of geomorphic changes on the Earth surface: toward evolutionary geomorphology. Earth Surface Processes and Landforms, Vol.34, pp. 891-896

Corenblit, D.; Baas, A.C.W.; Bornette, G.; Darrozes, J.; Delmotte, S.; Francis, R.A.; Gurnell, A.M.; Julien, F.; Naiman, R.J. \& Steiger, J. (2011). Feedbacks between geomorphology and biota controlling Earth surface processes and landforms: A review of foundation concepts and current understandings. Earth-Science Reviews, Vol.106, pp. 307-331

Cransac, N. \& Hewison, A.J.M. (1997) Seasonal use and selection of habitat by mouflon (Ovis gmelini): Comparison of the sexes. Behavioural Processes, Vol.41, pp. 57-67 
Delcourt, H.R. \& Delcourt, P.A. (1988). Quaternary landscape ecology: Relevant scales in space and time. Landscape Ecology, Vol. 2, pp. 23-44

Dorren, L.K.A.; Berger, F.; Imeson, A.C.; Maier, B. \& Rey, F. (2004). Integrity, Stability and Management of Protection Forest in the European Alps. Forest Ecology and Management, Vol.195, pp. 165-176

Dorren, L.K.A.; Berger, F.; Jonsson, M.; Krautblatter, M.; Mölk, M.; Stoffel, M. \& Wehrli, A. (2007). State of the art in rockfall - forest interactions. Schweiz Z. Forstwes., Vol.158, pp. 128-141

Edman, M. \& Jonsson, B.G. (2001).Spatial pattern of downed logs and wood-decaying fungi in an old-growth Picea abies forest. Journal of Vegetation Science, Vol.12, pp. 609-620

Evans, S.G. \& Clague, J.J. (1994) Recent climatic change and catastrophic geomorphic processes in mountain environments. Geomorphology, Vol.10, pp. 107-128

Fantucci, R. (1999). Dendrogeomorphology in landslide analysis. In: Floods and landslides: integrated risk assessment, R. Casale \& C. Margottini, (Eds.), 69-81, Springer-Verlag, Berlin

Franklin, J.F.; Shugart, H.H. \& Harmon, M.E. (1987). Tree death as an ecological process. Bioscience, Vol.37, pp. 550-556

Gärtner, H. (2007). Tree roots-Methodological review and new development in dating and quantifying erosive processes. Geomorphology, Vol.86, pp. 243-251

Gärtner, H.; Schweingruber, F.H. \& Dikau, R. (2001). Determination of erosion rates by analyzing structural changes in the growth pattern of exposed roots. Dendrochronologia, Vol.19, pp. 81-91

Gers, E.; Florin, N.; Gärtner, H.; Glade, T.; Dikau, R. \& Schweingruber, F.H. (2001). Application of shrubs for dendrogeomorphological analysis to reconstruct spatial and temporal landslide movement patterns. A preliminary study. Zeitschrift für Geomorphologie, Vol. 125 (Supplement), pp. 163-175

Govers, G. \& Poesen, J. (1998). Field experiments on the transport of rock fragments by animal trampling on scree slopes. Geomorphology, Vol.23, pp. 193-203

Grissino-Mayer, H.D. (1993). An updated list of species used in tree-ring research. Tree-Ring Bulletin, Vol.53, pp. 17-43

Gschwantner, T.; Schadauer, K.; Vidal, C.; Lanz, A.; Tomppo, E.; di Cosmo, L.; Robert, N.; Englert Duursma, D. \& Lawrence, M. (2009). Common Tree Definitions for National Forest Inventories in Europe. Silva Fennica, Vol.42, pp. 303-321

Gyssels, G.; Poesen, J.; Bochet, E. \& Li, Y. (2005). Impact of plant roots on the resistance of soil to erosion by water: a review. Progress in Physical Geography, Vol.29, pp. 189-217

Hack, J.T. \& Goodlett, J.C. (1960). Geomorphology and forest ecology of a mountain region in the Central Appalachians. U.S. Geological Survey Professional Paper 347.

Hall, K. \& Lamont, N. (2003). Zoogeomorphology in the Alpine: some observations on abiotic-biotic interactions. Geomorphology, Vol.55, pp. 219-234

Harmon, M.E. (2002). Moving towards a new paradigm for woody Detritus Management. USDA Forest Service Gen. Tech. Rep., PSW-GTR-181., pp. 929-944

Harmon, M.E.; Franklin, J.F.; Swanson, F.J.; Sollins, P.; Gregory, S.V.; Lattin, J.D.; Anderson, N.H.; Cline, S.P.; Aumen, N.G.; Sedell, J.R.; Lienkaemper, G.W.; Cromack, K. \& Cummins, K.W. (1986). Ecology of coarse woody debris in temperate ecosystems. Advances in Ecological Research, Vol.15, pp. 133-302 
Harmon, M.E.; Krankina, O.N. \& Sexton, J. (2000). Decomposition vectors: a new approach to estimating woody detritus decomposition dynamics. Canadian Journal of Forest Research, Vol.30, pp. 76-84

Hausmann, N.S. (2011). Biogeomorphology: understanding different research approaches. Earth Surface Processes and Landforms, Vol.36, pp. 136-138

Hengl, T. (2006). Finding the right pixel size. Computers \& Geosciences, Vol.32, pp. 1283-1298

Heroldova, M. \& Homolka, M. (2001). The introduction of mouflon into forest habitats: a desirable increasing of biodiversity? In: Proceedings of the third international symposium on mouflon. Sopron, Hungary, pp. 37-43

Hole, F.D. (1981). Effects of animals on soil. Geoderma, Vol.25, pp. 75-112

Hottola, J.; Ovaskainen, O. \& Hanski, I. (2009). A unified measure of the number, volume and diversity of dead trees and the response of fungal communities. Journal of Ecology, Vol.97, pp. 1320-1328

Hupp, C.R.; Osterkamp, W.R. \& Howard, A.D. (1995). Biogeomorphology - terrestrial and freshwater systems. Proceedings of the 26th Binghamton Symposium in Geomorphology. Geomorphology, Vol.13, 347 p.

Junninen, K. \& Komonen, A. (2011). Conservation ecology of boreal polypores: a review. Biological Conservation, Vol.144, pp. 11-20

Kauserud, H.; Colman, J.E. \& Ravarden, L. (2008). Relationship between basiodiospore size, shape and life history characteristics: a comparison of poylpores. Fungal Ecology, Vol.1, pp. 19-23

Kirkby, M.J. (1980). The problem. In: Soil erosion, M.J. Kirkby \& R.P.C. Morgan, (Eds.), 1-16, John Wiley \& Sons., Inc., New York

Lancaster, S.T.; Hayes, S.K. \& Grant, G.E. (2003). Effects of wood on debris flow runout in small mountain watersheds. Water Resources Research, Vol.39, pp. 1-21

Lindblad, I. (1998).Wood-inhabiting fungi on fallen logs of Norway spruce: relations to forest management and substrate quality. Nordic Journal of Botany, Vol.18, pp. 243256

Marston, R.A. (2010). Geomorphology and vegetation on hillslopes: interactions, dependencies, and feedback loops. Geomorphology, Vol.116, pp. 206-217

Masser, Ch.; Trappe, J.M.; Cline, S.P.; Cromack, K.; Blaschke, H.; Sedell, J.R. \& Swanson, F.J. (1984). The seen and unseen world of a fallen tree. General Technical Report PNW-164. U.S. Department of Agriculture, Portland

Matyja, M. (2007). The Significance of Trees and Coarse Woody Debris in Shaping the Debris Flow Accumulation Zone (North Slope of the Babia Gora Massif, Poland). Geographia Polonica, Vol.80, pp. 83-100

McCullough, H.A. (1948). Plant Succession on Fallen Logs in a Virgin Spruce-Fir Forest. Ecology, Vol.29, pp. 508-513

Naylor, L.A.; Viles, H.A. \& Carter, N.E.A. (2002). Biogeomorphology revisited: looking towards the future. Geomorphology, Vol.47, pp. 3-14

Panizza, M. (1996). Environmental geomorphology. Elsevier, Amsterdam.

Pérez, F.L. (2010). Biogeomorphic relationships between slope processes and globular Grimmia mosses in Haleakala's Crater (Maui, Hawaii). Geomorphology, Vol.116, pp. 218-235 
Perret, S., Stoffel, M. \& Keinholz, H. (2006). Spatial and temporal rockfall activity in a forest stand in the Swiss Prealps - a dendrogeomorphological case study. Geomorphology, Vol.74, pp. 219-213

Phillips, J. D. (1995). Biogeomorphology and landscape evolution: the problem of scale. Geomorphology, Vol.13, pp. 337-347

Phillips, J.D. (2009).Biological energy in landscape evolution. American Journal of Science, Vol.309, pp. 271-289

Phillips, J.D. \& Marion, D.A. (2006). Biomechanical effect of trees on soil and regolith: beyond treethrow. Annals of the Association of American Geographers, Vol.96, pp. 233247

Preston, N.J. \& Crozier, M.J. (1999). Resistance to shallow landslide failure through rootderived cohesion in east coast hill country soils, North Island, New Zealand. Earth Surface Processes and Landforms, Vol.24, pp. 665-675

Raska, P. (2007). Comments on the recent dynamics of scree slopes in the Czech Middle Mountains. Geomorphologia Slovaca et Bohemica, Vol.1, pp. 43-49

Raska, P. (2010). Types and character of geomorphic processes at Central-European lowaltitude scree slope (NW Czechia) and their environmental interpretation. Moravian Geographical Reports, Vol. 18, pp. 30-38

Raska, P. \& Orsulak, T. (2009). Biogeomorphic effects of trees on rock-mantled slopes: searching for dynamic equilibrium. Geograficky casopis, Vol.61, pp. 19-28

Reinhardt, L.; Jerolmack, D.; Cardinale, B.J.; Vanacker, V. \& Wright, J. (2010). Dynamic interactions of life and its landscape: feedbacks at the interface of geomorphology and ecology. Earth Surface Processes and Landforms, Vol.35, pp. 78-101

Rubiales, J.M.; Bodoque, J.M.; Ballesteros, J.A. \& Diez-Herrero, A. (2008). Response of Pinus sylvestris roots to sheet-erosion exposure: an anatomical approach. Natural Hazards Earth System Sciences, Vol.8, pp. 223-231

Schaetzel, R.J.; Johnson, D.L.; Burns, S.F. \& Small, T.W. (1989). Tree uprooting: review of terminology, process, and environmental implications. Canadian Journal of Forest Research, Vol.19, pp. 1-11

Scheidegger, A.E. (2004). Morphotectonics. Springer, Berlin-Heidelberg

Schowalter, T.D.; Caldwell, B.A.; Carpenter, S.E.; Groffiths, R.P.; Harmon, M.E.; Ingham, E.R.; Kelsey, R.G. Lattin, J.D. \& Moldenke, A.R. (1992). Decomposition of Fallen Trees: Effects of Initial Conditions and Heterotroph Colonization Rates. In: Tropical Ecosystems: Ecology and Management, K.P. Singh and J.S. Singh, (Eds.), 373-383, Wiley Eastern Limited, New Delhi

Schumm, S.A. \& Lichty, R.W. (1965). Time, space and causality in geomorphology. American Journal of Science, Vol.263, pp. 110-119

Schwarz, M.; Preti, F.; Giadrossich, F.; Lehmann, P. \& Or, D. (2010). Quantifying the role of vegetation in slope stability: A case study in Tuscany (Italy). Ecological Engineering, Vol.36, pp. 285-291

Sidle, R.C.; Pearce, A.J. \& O'Loughlin, C.L. (1985). Hillslope stability and land use. Water Resources Monograph, vol. 11. American Geophysical Union, Washington, DC

Silhan, K. \& Panek, T. (2010). Fossil and recent debris flows in medium-high mountains(Moravskoslezské Beskydy Mts, Czech Republic). Geomorphology, Vol.124, pp. 238-249 
Stefanini, M.C. (2004). Spatio-temporal analysis of a complex landslide in the Northern Apennines (Italy) by means of dendrochronology. Geomorphology, Vol.63, pp. 191202

Stine, M.B. \& Butler, D.R. (2011). A content analysis of biogeomorphology within geomorphology textbooks. Geomorphology, Vol.125, pp. 336-342

Stoffel, M. (2005).Assessing the vertical distribution and visibility of rockfall scars in trees. Schweiz. Z. Forstwes. Vol.156, pp. 195-199

Stoffel, M. (2010). Magnitude-frequency relationships of debris flows - A case study based on field surveys and tree-ring records. Geomorphology, Vol.116, pp. 67-76

Stoffel, M.; Schneuwly, D.; Bollschweiler, M.; Lievre, I.; Delaloye, R.; Myint, M. \& Monbaron, M. (2005). Analyzing rockfall activity (1600-2002) in a protection forest-a case study using dendrogeomorphology. Geomorphology, Vol.68, pp. 224-241

Stoffel, M. \& Perret, S. (2006). Reconstructing past rockfall activity with tree rings: Some methodological considerations. Dendrochronologia, Vol.24, pp. 1-15

Summerfield, M.A. (1991). Global geomorphology. An introduction to the study of landforms. John Wiley \& Sons., Inc., New York

Trimble, S.W. (1988). The impact of organisms on overall erosion rates within catchments in temperate regions. In: Biogeomorphology, H. Viles, (Ed.), 83-142, Basil Blackwell, Oxford

Trimble, S.W. \& Mendel, A.C. (1995). The cow as a geomorphic agent - A critical review. Geomorphology, Vol. 13, pp. 233-253

Vallauri, D.; André, J. \& Blondel, J. (2003). Le bois mort, une lacune des forêts gérées. Revue Forestière Française, Vol.2, pp. 99-112

Vanacker, V.; von Blanckenburg, F.; Govers, G.; Molina, A.; Poesen, J.; Deckers, J. \& Kubik, P. (2007). Restoring dense vegetation can slow mountain erosion to near natural benchmark levels. Geology, Vol. 35, pp. 303-306

Vandekerckhove, L.; Muys, B.; Poesen, J.; De Weerdt, B. \& Coppe', N. (2001). A method for dendrochronological assessment of medium-term gully erosion rates. Catena, Vol. 45, pp. $123-161$

Viles, H. (1988). Biogeomorphology. Basil Blackwell, Oxford

Volsamber, B. \& Veen, A. (1985). Digging by badgers and rabbits on some wooded slopes in Belgium. Earth Surface Processes and Landforms, Vol.10, pp. 79-82

Wainwright, J., Millington, J.D.A. (2010). Mind, the gap in landscape evolution modelling. Earth Surface Processes and Landforms, Vol.35, pp. 842-855

Wainwright, J., Parsons, A.J. (2010). Thornes, J.B. 1985: The ecology of erosion. Classics in physical geography revisited. Progress in Physical Geography, Vol.34, pp. 399-408

Wu, T.H.; McKinnell, W.P. \& Swanston, D.N. (1979). Strength of tree roots and landslides on Prince of Wales Island, Alaska. Canadian Geotechnical Journal, Vol. 16, pp. 19-33 


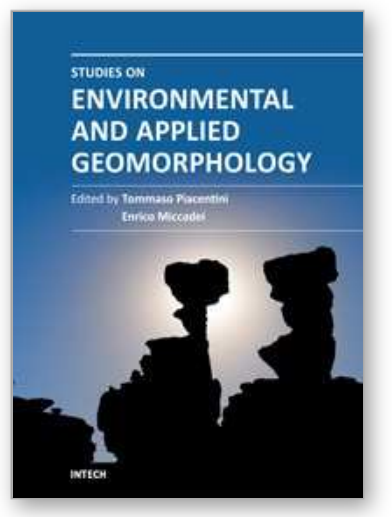

\author{
Studies on Environmental and Applied Geomorphology \\ Edited by Dr. Tommaso Piacentini
}

ISBN 978-953-51-0361-5

Hard cover, 294 pages

Publisher InTech

Published online 21, March, 2012

Published in print edition March, 2012

This book includes several geomorphological studies up-to-date, incorporating different disciplines and methodologies, always focused on methods, tools and general issues of environmental and applied geomorphology. In designing the book the integration of multiple methodological fields (geomorphological mapping, remote sensing, meteorological and climate analysis, vegetation and biogeomorphological investigations, geographic information systems GIS, land management methods), study areas, countries and continents (Europe, America, Asia, Africa) are considered.

\title{
How to reference
}

In order to correctly reference this scholarly work, feel free to copy and paste the following:

Pavel Raška (2012). Biogeomorphologic Approaches to a Study of Hillslope Processes Using Non-Destructive Methods, Studies on Environmental and Applied Geomorphology, Dr. Tommaso Piacentini (Ed.), ISBN: 978953-51-0361-5, InTech, Available from: http://www.intechopen.com/books/studies-on-environmental-andapplied-geomorphology/biogeomorphologic-approaches-to-a-study-of-hillslope-processes-using-nondestructive-methods

\section{INTECH}

open science | open minds

\section{InTech Europe}

University Campus STeP Ri

Slavka Krautzeka 83/A

51000 Rijeka, Croatia

Phone: +385 (51) 770447

Fax: +385 (51) 686166

www.intechopen.com

\section{InTech China}

Unit 405, Office Block, Hotel Equatorial Shanghai

No.65, Yan An Road (West), Shanghai, 200040, China

中国上海市延安西路65号上海国际贵都大饭店办公楼 405 单元

Phone: +86-21-62489820

Fax: $+86-21-62489821$ 
(C) 2012 The Author(s). Licensee IntechOpen. This is an open access article distributed under the terms of the Creative Commons Attribution 3.0 License, which permits unrestricted use, distribution, and reproduction in any medium, provided the original work is properly cited. 